\title{
Research on Integrated Auditing of Listed Companies in China
}

\author{
Cheng Huanling \\ Xi'an International University, business school, Shaanxi,xian,710077,China
}

Keywords: Integrated Auditing, Listed Companies, China

\begin{abstract}
In 2010, the relevant departments of our country promulgated the Guidelines on Audit of Enterprise Internal Control, which explicitly asked the listed companies to carry out self-evaluation and external audit on the effectiveness of internal control. This shows that the listed companies in China must audit the internal control in the future and ensure the listing the quality of the company's internal control. Therefore, the integrated audit of listed companies came into being. At present, it discusses the feasibility and necessity of the integration of internal control audit and financial statement audit, and puts forward the methods and strategies to strengthen the integrated audit, which is of great practical significance to improve the financial information quality of listed companies.
\end{abstract}

\section{Introduction}

The public audits of financial statements can ensure that the quality of financial information of listed companies begins to be questioned after the Enron incident in the United States. For this reason, the United States promulgated a bill, the bill clearly put forward a new requirement that the company management is responsible for the company's financial reporting on the effectiveness of internal control to fully assess, and then certified by the accounting firm assessment results and issued a corresponding audit report From the overall integration of the financial statements audit and financial reporting internal control audit, in order to fundamentally solve the problem of financial information quality purposes. Consolidated audits of financial statements audits and financial reports Internal control audits are presented by the US Listed Companies Accounting Oversight Board in the promulgated No. 5 audit guidelines and emphasize the use of top-down approaches based on risk-oriented requirements. In our country in April 2010 issued by the "internal control audit guidance" in the internal control audit will begin in 2011 in the listed companies to gradually carry out, which also makes the financial statements audit and internal control audit into the integrated audit stage.

\section{The Necessity and Feasibility for Integrated Audit}

The Necessity for Integrated Audits. Cost factor is a key factor in the development of integrated audit of listed companies. In the process of internal control audit, the cost of the problem has become a constraint on the development of internal control. In the early years, many agencies suggested that internal controls should be included in the scope of corporate information disclosure, but did not materialize for cost reasons. At present, the annual audit fee of the financial report of the listed company has already cost a lot of money for the enterprise, and the increase of the internal control audit business will bring a greater burden to the listed companies. However, with the emergence of financial fraud, such as Enron fraud, the management must pay attention to the system to control financial risk, therefore, the internal control report has become a listed company must disclose and audit the report. Consolidated audits can not only reduce the financial risk of listed companies, but also improve the audit efficiency of listed companies. Financial statements audit and internal control audit is the responsibility of the party's business, are part of the authentication business, which are reasonable to ensure business. If the two audits are integrated, the two audits can be carried out simultaneously, sharing all the information resources, reducing the financial burden of the accounting firm, thereby reducing the audit fees of the audited listed 
companies. It can be seen that the integration audit can improve the audit efficiency of auditors and control the audit risk, but also can improve the authenticity and reliability of the financial report information of listed companies.

The Feasibility of Integrated Audit. There is a relationship between the audit of financial statements and the internal control audit, which determines the operability of the integrated audit. First, the purpose of both the audit of the financial statements and the internal control audit is the same. The purpose of the two audits is to provide reasonable assurance to the financial information of the listed company and the quality of other information so as to facilitate the information users' Information to make the right economic decision. Second, the audit methods are roughly the same. The process of internal control audit is to understand the overall risk of internal control first, and then identify the control of the enterprise level, and then identify the level of risk identified. As can be seen from the above, the internal control audit also uses a risk-oriented audit method. Consistency of the two audit methods will help to integrate the smooth development of the audit work.

\section{The Implementation Ideas and Key Points of Integrated Audit}

The current accounting report audit concept is based on the audit is based on the audit standards, through the planning and implementation of the audit business, the financial statements of the legal attributes and fairness of the audit recommendations, the original intention is to enhance the reliability of financial statements. The concept of internal control audit is that the accounting firm accepts the entrustment, audits the reliability of the internal control of the enterprise before the establishment, and gives the audit recommendations. The scope of internal control audit mentioned here is the audit proposal that the enterprise plans and uses for the scientific and financial accounting report and the reliable and comprehensive information. In fact, it is the internal control business of the accounting report. The author in this article to study the concept of integrated audit is the same accounting firm on the same audit institutions to implement internal audit and accounting statements audit, accounting for accountants to integrate planning and audit operations, and take into account the purpose of both.

Chinese "basic norms of internal control" to accurately locate the internal control should achieve the five goals, that is, enterprises in a reasonable guarantee of business management legal compliance, asset security, financial reports and related information is true and complete, improve operational efficiency and effectiveness, Focus on promoting enterprises to achieve development strategy. For enterprises, the Ministry of Finance and other five ministries asked them to stand in the height of the five control objectives, the establishment, implementation and maintenance of effective internal control, and the effectiveness of the entire internal control evaluation, issued self-evaluation report. For the CPA, audit is conducted on the effectiveness of the internal control of financial reporting and related information in accordance with the requirements of international convergence and the actual situation of the CPA industry. The main objective of the audit of the financial statements is to express an opinion on the legality and fairness of the financial statements. It can be seen how the integration of the two audit objectives is how to work together to improve the reliability of financial statements and provide high-quality financial information.

From the integration point of the audit target to the integration point of the implementation process, the procedures implemented by the internal control audit are mainly the risk assessment procedure and the control test. The risk assessment procedure is the basis of the whole internal control audit. The control test is the internal control audit Core program. The financial statements audit implementation procedures include risk assessment procedures, internal control tests and substantive testing. In accordance with the requirements of modern risk-oriented audits, the risk assessment process also includes understanding of internal controls and, in assessing the risk of a material misstatement The control of the operation is effective or only the implementation of substantive procedures is not sufficient to provide a sufficient level of appropriate audit evidence, it is necessary to carry out internal control tests 


\section{The Specific Implementation of the Integration Audit Method}

The Planning Stage of the Audit Work. In the development of the audit plan, the first should determine the level of the importance of acceptable, certified public accountants to use professional experience and professional judgment to determine the level of importance. The level of importance of the judgment is based on whether the internal control prevents or discovers a material misstatement in the financial statements and, if it cannot be achieved, indicates that there is a significant flaw in internal control. It can be seen that the internal control audit and financial statements of the importance of the audit method is consistent. When the accounting firm conducts an integrated audit of the audit of the financial statements and the internal control audit, it should consider the characteristics of the two audit contents and develop the audit plan at the same time to ensure that the audit process can be carried out in a coordinated manner and improve the efficiency of the audit work. When developing an audit plan, the certified public accountant should consider whether certain matters have an impact on both internal control and financial statements, and the way these matters affect the audit process.

Risk Assessment Procedures. Risk-oriented audit requires that the first step in auditing financial statements is to understand the audited entity and the environment, and only to understand the specific circumstances of the audited entity in order to make an accurate level of importance. The first step in the internal control audit is also to understand the audited units and the environment. Therefore, in the case of integrating the two audits together, it is possible to understand the audited unit and its environment once. In the implementation of the audit unit and its environment, the internal control audit requirements higher, therefore, the CPA should be in accordance with the "Guidelines for the application of internal control" to understand the situation of the audited units. And the financial statements audit direct use of internal control audit in the first step results can be. Risk assessment is the prerequisite for the implementation of integrated audits. In the audit of the financial statements, the auditors should adequately identify and assess the risk of material misstatement in the financial statements in order to facilitate the design and implementation of further audit procedures. In the process of audit internal control, the auditor should adopt a risk-oriented approach and a top-down audit method to select the control procedures that need to be tested. The internal control of the listed company is divided into the internal control and the internal control of the listed company level. The overall level of control of listed companies determines the effectiveness of internal control, directly related to the internal control audit in the business level control test range.

Risk Response Procedures. The risk response process is mainly to control the testing and substantive procedures. When considering how to choose to be controlled and tested, the CPA should consider the importance of the evidence and control the ease of implementation in order to facilitate the smooth conduct of the control test. When the internal control of the control test found that there are one or more major defects, the listed company's internal control should be considered invalid. Therefore, when the audit staff to identify major deficiencies in internal control, should be in the financial statements audit will be a related identified risk of control as a higher level. At the time of the audit of the certified public accountants, the auditors should further evaluate the internal control and carry out the control tests in time while carrying out the substantive testing procedures, and use the certified public accountants to judge whether the internal control defects alone or in combination constitute a major defect. In the form of adequate audit evidence issued financial statements audit and internal control audit opinion.

Special Consideration for Fraud. Whether the audit of financial statements or internal control audit requires attention to the discovery and audit of fraud, therefore, in the integration of the audit, the CPA should pay more attention to fraud issues. In the financial information of listed companies, fraud is often related, so the integration of the audit process should pay attention to the details of the problem, should pay attention to the following links. First, the auditors in the internal control of five elements in one or several elements when there is doubt, the auditors should be vigilant. Second, the auditors should be aware of the common management of fraud, management fraud is a high risk of auditing areas, due to the audit staff and listed companies within the management of the information 
asymmetry between the audit failure is likely to occur. In addition, when the internal control audit found a major flaw, it directly affects the implementation of the audit of the financial statements, because the internal control audit and financial reporting audit are interrelated

Issue An Audit Report. The CPA should carefully implement each procedure of the consolidated audit, evaluate the risk of material misstatement and the internal control deficiencies, and carefully consider whether sufficient audit evidence is available to determine the risk of material misstatement or significant internal control Misstate the risk, and then publish the audit opinion and audit report. In the formation of audit opinions and audit reports issued by the CPA should be comprehensive evaluation In the integrated audit, each audit conclusion and other part of the audit conclusion is mutual confirmation, mutual support, the auditors should perform control tests, and come to internal control Whether the audit is valid. In order to improve the efficiency of the audit, we should explore in depth the possibility of allowing the CPA to choose to issue the audit report separately and separately to issue the audit report. In accordance with the Guidelines on Auditing of Internal Control in China, the certified public accountants should issue audit reports respectively.

\section{Conclusion}

In summary, the integrated audit can help improve the audit efficiency and improve the quality of financial information, and the implementation of integrated audit in Chinese listed companies has its necessity and feasibility, in the audit practice audit plan stage, risk assessment stage, risk response stage, special considerations for fraud, issue of audit reports and other links are also operational. Therefore, in-depth study to improve the level of integration of audit methods and has a reference significance for the audit practice.

\section{References}

[1] Z. Y. Hong, Meng Qinglin, Fu Rong. Standardized internal control audit strategy and practice [J]. Popular electricity. 2015 (S1)

[2] L.Z. Da. Internal control audit problem research [J]. Administrative assets and finance. 2017 (10)

[3] S. Guo. Min. Analysis of the optimization of internal control of state-owned enterprises countermeasures [J]. Accountants. 2017 (07)

[4] C.Chen. Internal control audit system on the impact of funds [J]. National circulation of the economy. 2017 (06)

[5] D. Nan. Analysis of the Correlation between Internal Control Audit and Financing Cost of Listed Companies [J]. Statistics \& Decision. 2017 (09)

[6] C. Yan. Compulsory rules after the internal control audit research summary - based on the influencing factors and economic consequences [J]. Finance and Accounting. 2017 (13)

[7] Li Yang, Li Guoxu, Geng Di.Study on the thinking and method of enterprise internal control audit [J]. Farms Economic Management. 2017 (01) 